\title{
THE ROMANIAN BANK GREDIT SYSTEM DURING THE INTERWAR PERIOD. THE ECONOMIC PERSPECTIVE OF MITIȚĂ CONSTANTINESCU
}

\author{
Gabriela BODEA ${ }^{\mathrm{a}, *}$, Ioana-Sorina MIHUT, ${ }^{\mathrm{b}}$ \\ a),b) Babeş-Bolyai University, Faculty of Economics and Business Administration, \\ Cluj-Napoca, Romania
}

Please cite this article as:

Article History:

Bodea, G. and Mihuț, I.S., 2017. The Romanian bank credit system during the interwar period. The Received: 7 December 2016 economic perspective of Mitiță Constantinescu. Review of Economic Studies and Research Virgil Madgearu, 10(1), pp.5-17. doi: 10.24193/RVM.2017.10.01.

Abstract: The "Great Depression" from 1929-1933 caused a series of negative effects upon the worldwide economies, which highlighted a wide range of shortcomings these economies were confronting long time ago. Romania had to face one of the most important sustainability tests in the history. The solutions elaborated by the economists of that time concentrated upon the development of recovery plans and the optimal use of the financial resources. One of the key sector taken into consideration was the banking system. The main purpose of this article is to present a short review considering the role of the bank credit, as an instrument in promoting economic growth and development, in the view of Mitită Constantinescu, the Governor of the Romanian National Bank between 1938 and 1939. As a man of state and of finance, Mitiţă Constantinescu tried to reorganize and modernize it, in order to respond to the specific needs of the society.

Key words: financial crisis; credit system; monetary policy JEL Classification: $B 25 ; B 26 ; E_{51} ; E_{52} ; E_{5} 8$

(C) 2017 Alma Mater Publishing House. All rights reserved.

* Corresponding author. E-mail address: gabriela.bodea@econ.ubbcluj.ro. 


\section{References}

1. Blejan, E., Costache, B., Aloman, A., 2009. The National Bank of Romania during The Great Depression 1929-1933. In: Economic and Financial Stability in SE Europe in a Historical and Comparative Perspective. Fourth Conference of Southeast Europe Monetary History Network (SEEMHN). Belgrade, available online at: https://www. nbs.rs/internet/latinica/90/seemhn/seemhn_conf/SEEMHN_14_ Rumunija.pdf.

2. Constantinescu, M., 1943. Politică economică aplicată. In: Producţie. Muncă. Comerţ. Credit., vol. 3. Bucureşti: Editura Tiparul Românesc, SAR.

3. Enciclopedia României, 1938. $1^{\text {st }}$ edition, vol. IV, București: Imprimeria Naţională.

4. Kossev, K.D., 2008. The banking sector and the great deppresion in Bulgaria, 1924-1938: interlocking and financial sector profitability. Athena: Bank of Greece, Economic Research Department - Special Studies Division.

5. Madgearu, V., 1940. Evoluţia economiei româneşti după războiul mondial, Bucureşti: Independenţa Economică.

6. Mihuț, I.S., 2014. Spre convergență economică într-o lume a divergențelor, Cluj-Napoca: Presa Universitară Clujeană.

7. Rosentuler, S., Salater, W., Slăvoiu, O. and Mariţiu, S., 2001. Viaţa și opera lui Victor Slăvescu. In: Isărescu, M. Restitutio. București: Banca Națională a României.

8. Rosentuler, S., Salater, W. and Mariţiu, S., 2002. Viața și opera lui Virgil Madgearu. In Isărescu, M. Restitutio. București: Banca Națională a României.

9. Rosentuler, S., Mariţiu, S., Soare, I. and Dumitrescu, A., 2004. Viața și opera lui Mitiță Constantinescu. In Isărescu, M. Restitutio. București: Banca Națională a României.

10. Slăvescu, V., 1937. Aspectele crizei românești în cadrul crizei mondiale. Bucureşti: Tipografia Bucovina. 